\title{
Menggagas Terbentuknya \\ Islamic Calendar Research Network (ICRN)
}

Tono Saksono

tsaksono@gmail.com

\begin{abstract}
Abstrak
Persoalan Kalender Islam masih merupakan persoalan besar umat Islam hari ini. Persoalan Kalender Islam sendiri menyimpan persoalan syariah yang sangat serius. Penelitian tentang Kalender Islam belum banyak dilakukan, oleh karena itu ia perlu digalakkan dan harus betul-betul efisien dan efektif. Keberadaan dan kehadiran Islamic Calendar Research Network (ICRN) sendiri menjadi sangat penting sebagai pengendali efektifitas investasi dan arah penelitian (dalam tingkat S1 sampai dengan S3). ICRN dapat juga berperan sebagai semacam clearing house dengan tugas-tugas strategis untuk memberikan informasi atas arah, kepentingan, dan masa depan penelitian yang terkait dengan Kalender Islam. Ini merupakan kelompok think tank tempat berkumpulnya para pakar Kalender Islam.
\end{abstract}

Semua bank syariah di dunia tampaknya telah berpraktek ekonomi syariah yang semu (pseudo)

\section{Kata Kunci: Kalender Islam, ICRN, peradaban}

\section{Pendahuluan}

Setelah sekitar 14 abad menyebar di seluruh dunia dengan jumlah ummatnya yang mencapai 1,6 miliar [1], sungguh malang bahwa ummat Islam belum memiliki sebuah kalender Islam yang kredibel dan dapat digunakan sekaligus sebagai rujukan manajemen waktu ummatnya baik untuk kehidupan spiritual dan muamalah (perdagangan, pendidikan, administrasi sosial, dll). Persoalan kalender Islam yang kita hadapi saat ini sebetulnya adalah merupakan problem peradaban umat Islam, bukan hanya problem astronomi. Lebih spesifik lagi, ia merupakan ancaman atas peradaban umat Islam. Akibat tiadanya kalender Islam, umat Islam telah menggunakan kalender Gregorian sebagai basis akuntansi dalam mengelola bisnisnya. Namun, karena kalender Gregorian adalah 11.5 hari lebih panjang dari kalender Islam, maka telah terjadi kekurangan pembayaran zakat.

Akibat penggunaan kalander Gregotian, secara konseptual dan syar'i, pembayaran zakat umat Islam dengan demikian telah mengalami defisit sekitar 3,15\% per tahun. Celakanya, kesalahan ini mungkin telah berlangsung selama ratusan tahun, atau bahkan lebih dari seribu tahun. Tidak dapat disangsikan lagi, hal ini telah membentuk bola salju hutang peradaban umat Islam yang telah menumpuk menjadi triliunan dolar. Hutang peradaban ini harus dihentikan jika kita tak ingin mewariskannya pada anak-cucu kita. Jika umat Islam bersedia untuk memperbaiki kesalahan ini, umat Islam sebetulnya memiliki potensi ekonomi yang sangat luar biasa. Dengan potensi ini, kemiskinan di dunia Islam sebetulnya akan dapat dihilangkan tanpa bantuan lembaga donor seperti Bank Dunia, IMF, dan lain-lain. 


\section{Ancaman atas Pradaban Umat Islam}

Salah satu dampak tiadanya kalender Islam adalah dalam cara pendefinisian sistem akuntansi bisnis umat Islam. Sebuah entitas bisnis wajib untuk memberikan laporan laba-rugi pada setiap akhir tahun fiskal. Atas dasar laporan inilah, perusahaan tersebut kemudian di antaranya membayar:

a) Hutang-hutang perusahaan untuk keperluan operasinya;

b) Membayar zakat;

c) Membayar pajak;

d) Menahan sebagian keuntungan untuk pengembangan usaha;

e) Membagikan dividen pada para pemegang saham;

f) Membagikan bonus tahunan bagi manajemen dan karyawan.

Problemnya adalah ketika sistem akuntansi perusahaan ini mengadopsi sistem kalender Gregorian, maka untuk setiap 30 tahun operasi perusahaan ini, zakat yang tidak terbayarkan akan menumpuk menjadi sekitar satu tahun baik di level individual maupun korporasi. Meskipun dalam level individual kita telah berupaya melaksanakan pembayaran zakat pada bulan Ramadan, namun, jika dividen, dan bonus tahunan umat diterimakan dengan perhitungan kalender Gregorian, maka potensi defisit pembayaran zakat tersebut tetap melekat.

Apalagi, dengan semakin mudahnya penguasaan atas paper assets yang semakin mudah di dunia virtual, akan semakin mudah pula umat Islam melupakan hutang akibat kekurangan pembayaran zakat ini. Hanya dalam rentang waktu haul 4.5 sampai 19.4 tahun dan dengan jumlah paper asset sekitar 10 juta lembar saham saja, hasil simulasi hutang peradaban pada Tabel-1 [2] telah mencapai angka sekitar US\$ 10 juta. Sementara itu, perhitungan defisit zakat atas 22 korporasi multi-nasional (baca: seandainya mereka adalah korporasi Muslim) dengan rentang haul yang hanya sekitar 10 tahun diperlihatkan pada Tabel-2 [3]. Nilai defisit zakatnya sendiri menunjukkan lebih dari 350 juta US\$ (kolom 7). Algoritma lengkap tentang perhitungan defisit zakat ini dapat dilihat pada Saksono [4].

Dengan demikian, bila penggunaan kalender Islam dalam kehidupan muamalah ini telah kita tinggalkan dalam rentang 1200 tahun, maka seluruh umat Islam sebetulnya mungkin dalam keadaan bangkrut. Harus diingat bahwa hutang peradaban yang kita warisi ini akan kita wariskan pula pada anak cucu kita jika kita tidak melakukan apa-apa untuk menghentikannya sejak sekarang. Jika ada orang yang menganggap sepele saja persoalan hutang pada Allah, sudah dapat dipastikan orang ini sedang sakit secara spiritual. 
Tabel 1: Defisit pembayaran zakat atas kepemilikan lima jenis paper assets

\begin{tabular}{|c|c|c|c|c|c|c|}
\hline ASSETS & VOLUME & $\begin{array}{l}\text { PERIOD } \\
\text { (Year) }\end{array}$ & $\begin{array}{l}\text { ZAKAI } \\
\text { (Greg. Cal. } \\
\text { IKS\$) }\end{array}$ & $\begin{array}{c}\text { ZAKAI' } \\
\text { (Islamic Cal. } \\
\text { IJS\$) }\end{array}$ & $\begin{array}{l}\text { Zakat deficit } \\
\text { (US\$) }\end{array}$ & $\begin{array}{c}\text { Kelative } \\
\text { Accuracy } \\
\text { (\%) }\end{array}$ \\
\hline 1 & 2 & 3 & 4 & 5 & 6 & 7 \\
\hline $\begin{array}{l}\text { Gencral } \\
\text { Flectric }\end{array}$ & $\begin{array}{l}10 \text { million } \\
\text { shares }\end{array}$ & 9.5 & $81,583,329$ & $83,968,940$ & $2,385,611$ & 1.69 \\
\hline Gold & $\begin{array}{l}1,(000),(1000 \\
\text { ounces }\end{array}$ & 19.4 & $206,622,239$ & $212,048,171$ & $5,425,932$ & 0.28 \\
\hline Silver & $\begin{array}{l}1,000,000 \\
\text { ounces }\end{array}$ & 12.8 & $3,537,163$ & $3,643,871$ & 106,708 & 1.25 \\
\hline Crude oil & $\begin{array}{l}10 \text { million } \\
\text { barrels }\end{array}$ & 4.5 & $41,781,151$ & $42,97(1,881$ & $1,189,730$ & 1.38 \\
\hline Copper & $\begin{array}{l}10 \text { million } \\
\text { units }\end{array}$ & 16.0 & $7,403,671$ & $7,478,343$ & 74,671 & 1.71 \\
\hline
\end{tabular}

Tabel 2: Defisit pembayaran zakat jika korporasi berikut adalah bisnis Muslim

\begin{tabular}{|c|c|c|c|c|c|c|}
\hline & & Period & $\begin{array}{c}\text { Total Net } \\
\text { Income }\end{array}$ & $\begin{array}{l}\text { Zakat } \\
\text { (G) }\end{array}$ & $\begin{array}{l}\text { Zakat } \\
\text { (H) }\end{array}$ & $\begin{array}{l}\text { Zakat } \\
\text { Deficit }\end{array}$ \\
\hline CONIFAINY & From- 10 & (year) & (US\$ mill) & $\begin{array}{l}\text { (US\$ } \\
\text { mill) }\end{array}$ & $\begin{array}{l}\text { (US\$ } \\
\text { mill) }\end{array}$ & $\begin{array}{l}\text { (US\$ } \\
\text { mill) }\end{array}$ \\
\hline 1 & 2 & 3 & 4 & 5 & 6 & 7 \\
\hline 3M & 31/03/04 - & 10.50 & & & & \\
\hline & $30 / 6 / 14$ & & 40,734 & 83.9 & 85.5 & 1.53 \\
\hline Amex & $\begin{array}{l}31 / 03 / 04- \\
30 / 6 / 14\end{array}$ & 10.50 & 41,521 & 85.5 & 87.1 & 1.56 \\
\hline Apple & $\begin{array}{l}31 / 03 / 04- \\
30 / 6 / 14\end{array}$ & 10.50 & 169,850 & 350.3 & 359.3 & 9.01 \\
\hline Chevron & $\begin{array}{l}31 / 03 / 04- \\
30 / 6 / 14\end{array}$ & 10.50 & 201,358 & 414.3 & 426.1 & 11.75 \\
\hline JPMorgan & $\begin{array}{l}31 / 03 / 04- \\
30 / 6 / 14\end{array}$ & 10.50 & 142,040 & 289.6 & 297.4 & 7.85 \\
\hline Wells Fargo & $\begin{array}{l}31 / 03 / 04- \\
30 / 6 / 14\end{array}$ & 10.50 & 116,839 & 245.3 & 251.1 & 5.71 \\
\hline $\begin{array}{l}\text { United } \\
\text { Technologies } \\
\end{array}$ & $\begin{array}{l}31 / 03 / 04- \\
30 / 6 / 14\end{array}$ & 10.50 & 45,617 & 94.0 & 96.0 & 2.01 \\
\hline Amgen & $\begin{array}{l}31 / 03 / 04- \\
30 / 6 / 14\end{array}$ & 10.50 & 41,310 & 85.5 & 86.8 & 1.34 \\
\hline Coca-Cola & $\begin{array}{l}31 / 03 / 04- \\
30 / 6 / 14\end{array}$ & 10.50 & 75,609 & 154.2 & 158.3 & 4.07 \\
\hline Conocophillips & $\begin{array}{l}31 / 03 / 04- \\
30 / 6 / 14\end{array}$ & 10.50 & 82,629 & 230.4 & 237.9 & 7.45 \\
\hline Exxon & $\begin{array}{l}31 / 03 / 04- \\
30 / 6 / 14\end{array}$ & 10.50 & 372,930 & 767.7 & 790.3 & 22.60 \\
\hline GE & $\begin{array}{l}31 / 03 / 04- \\
30 / 6 / 14\end{array}$ & 10.50 & 161,659 & 332.0 & 424.3 & 92.36 \\
\hline
\end{tabular}




\begin{tabular}{|c|c|c|c|c|c|c|}
\hline Google & $\begin{array}{l}31 / 03 / 03- \\
31 / 03 / 12\end{array}$ & 9.00 & 68,601 & 110.5 & 113.5 & 2.97 \\
\hline Intel & $\begin{array}{l}31 / 03 / 04- \\
30 / 6 / 14\end{array}$ & 10.50 & 87,618 & 181.1 & 184.7 & 3.55 \\
\hline McDonald & $\begin{array}{l}31 / 03 / 04- \\
30 / 6 / 14\end{array}$ & 10.50 & 43,776 & 91.0 & 92.2 & 1.22 \\
\hline Microsoft & $\begin{array}{l}31 / 03 / 97- \\
31 / 12 / 11\end{array}$ & 14.80 & 177,998 & 967.2 & 994.1 & 26.87 \\
\hline PG & $\begin{array}{l}31 / 03 / 04- \\
30 / 6 / 14\end{array}$ & 10.50 & 111,275 & 228.6 & 234.4 & 5.79 \\
\hline Qualcomm & $\begin{array}{l}31 / 03 / 04- \\
30 / 6 / 14\end{array}$ & 10.50 & 40,576 & 82.4 & 85.3 & 2.88 \\
\hline Schlumberger & $\begin{array}{l}31 / 03 / 04- \\
30 / 6 / 14\end{array}$ & 10.50 & 45,561 & 92.8 & 96.1 & 3.22 \\
\hline Total & $\begin{array}{l}31 / 03 / 04- \\
30 / 6 / 14\end{array}$ & 10.50 & 151,725 & 313.8 & 324.4 & 10.59 \\
\hline Toyota & $\begin{array}{l}31 / 03 / 04- \\
30 / 6 / 14\end{array}$ & 10.50 & 97,098 & 217.2 & 348.4 & 131.20 \\
\hline Walt Disney & $\begin{array}{l}31 / 03 / 04- \\
30 / 6 / 14\end{array}$ & 10.50 & 46,693 & 95.2 & 97.1 & 1.86 \\
\hline
\end{tabular}

Dari kedua fakta dengan penggunaan sampel data yang terbatas ini saja, jelaslah bahwa praktek ekonomi shariah yang selama ini kita miliki sebetulnya merupakan pseudo shariah economy. Rupanya, energi umat Islam di dunia selama ini terlalu tersita untuk mendiskusikan hanya isu-isu tentang riba (bunga), gharar (subhat), dan maysir (judi) sebagai tiga faktor yang membedakan praktik ekonomi shariah dari ekonomi konvensional. Padahal, sebetulnya ada sebuah faktor lain yang tidak kalah pentingnya, yaitu isu tentang haul. Sangatlah naif jika umat Islam berkutat dengan ketiga isu di atas, sementara isu haul ternyata telah menyebabkan semakin menumpuknya hutang pada kaum miskin akibat kekurangan membayar zakat. Hutang pada kaum miskin ini sejatinya adalah hutang pada Allah SWT, dan penyebabnya adalah karena kita telah melupakan penggunaan kalender Islam sebagai basis akuntansi bisnis Muslim.

\section{Tren Dunia dalam Penyusunan Kalender Islam}

Dengan mengamati keputusan para pakar dan ulama internasional dalam mengawali Ramadan 1435-H yang lalu, Saksono [2] mengelompokkan adanya tujuh (7) mazhab berbeda dalam penyusunan kalender Islam. Bagian ini sekaligus juga menunjukkan adanya gambaran tren pembangunan Kalender Islam Global yang sangat kuat di masa yang akan datang. Ketujuh mazhab pembangunan kalender Islam ini secara singkat dijelaskan sebagai berikut.

\section{A. 3.1 Saudi Arabia}

Saudi Arabia adalah satu-satunya negara di dunia yang menggunakan Kalender Islam sebagai kalender resmi untuk keperluan sipil (administrasi, bisnis, pendidikan, dll.), kecuali di sektor-sektor yang berhubungan erat dengan dunia internasional (misal: jadwal penerbangan pesawat). Kalender Islam yang berlaku di 
Arab Saudi dikembangkan oleh Umm al-Quro University (UQU). Semula UQU menggunakan metoda imkan-rukyat dengan ketinggian hilal minimum $9^{\circ}$. Namun, sudah sekitar 40 tahun, ini ditinggalkan dan pindah ke metoda Wujudul Hilal lokal [5]. Akan tetapi, khusus untuk penetapan awal bulan Ramadan, Syawal, dan DzulHijjah, kalender UQU dapat dibatalkan oleh Mahkamah Agung setelah menerima kesaksian melihat hilal atau tidak melihat hilal (rukyatul hilal) yang bersumpah. Ini adalah salah satu contoh tidak reliable-nya kalender Islam.

\section{B. 3.2 Amerika Serikat dan Kanada}

Islamic Society of North America (ISNA) dan the Fiqh Council of North America (FCNA), sampai dengan tahun 2006, sebetulnya menggunakan metoda Rukyatul Hilal $(\mathrm{RH})$ untuk penyusnan kalender Islam untuk keperluan ibadah umat Islam di Amerika Utara. Untuk keperluan pengembanggannya, selama sekitar 13 tahun (dari 1994 s/d 2006), ISNA telah melakukan riset experimental untuk melakukan rukyatul hilal di seluruh Amerika Utara, dengan menyebar sekitar 2000 perukyat (sukarelawan) ke seluruh Amerika Utara (AS dan Kanada) setiap bulan [6]. Namun, upaya experiment RH tersebut akhirnya gagal, makanya ISNA/FCNA beralih menggunakan WH lokal dengan basis hitungannya adalah koordinat kota Mekah di Arab Saudi.

Inilah bukti lagi silang-sengkarutnya isu kalender Islam yang kita miliki sekarang ini. Sementara ISNA mengacu pada kondisi hilal lokal di Mekah, tapi Saudi Arabia sendiri malah sering bertentangan dengan kriteria wujudul hilal. Pada 27 Juni 2014 lalu, Matahari tenggelam di Mekah pada jam 19:10, sementara Bulan tenggelam hanya satu menit kemudian pada 19:11. Berarti di kota Mekah sebetulnya hilal telah wujud pada maghrib 27 Juni 2014 tersebut dengan ketinggian hilal $0.3^{\circ}$ (dengan referensi lokal Mekah). Kondisi wujudul hilal yang rendah ini sudah dianggap cukup bagi ISNA untuk menetapkan awal puasa untuk Amerika Utara pada 28 Juni 2014. Ini sesuai pula dengan Kalender UQU yang menetapkan awal Ramadan yang jatuh pada 28 Juni 2014. Namun, Mahkamah Agung Saudi Arabia sendiri menganulir kalender UQU ini karena tidak ada kesaksian yang dapat merukyat hilal pada maghrib 27 Juninya. Dengan demikian kerajaan Arab Saudi secara resmi menetapkan awal Ramadan justru jatuh pada 29 Juni 2014.

\section{3.3 Turki}

Turki adalah satu-satunya negara yang secara terbuka masih menganut madzhab imkan-rukyat (IR) dengan kriteria tinggi hilal minimum $5^{\circ}$, dan sudut elonagsi minimum $8^{\circ}$. Namun, kriteria IR ini tampaknya telah ditinggalkan dalam beberapa tahun terakhir. Kita dapat lihat data astronomis ketinggian hilal di beberapa kota di Turki pada maghrib 27 Juni 2014 lalu:

Izmir: $-1.2^{\circ}$

Adana: $-1.3^{\circ}$

Ankara: $-1.6^{\circ}$

Istanbul: $-1.6^{\circ}$

Ini berarti, pada maghrib 27 Juni 2014 lalu di seluruh wilayah teritori politik Turki, kondisi hilal sebetulnya masih di bawah ufuk. Namun, pemerintah Turki secara 
resmi menetapkan awal Ramadan adalah pada 28 Juni 2014. Dengan demikian, dalam beberapa tahun terakhir, Turki mungkin malah telah mengadopsi dan pindah ke Ijtima Qobla al-Ghurub (IQG), atau mengikuti Kalender Islam Global seperti ketentuan European Council for Fatwa and Research (ECFR).

\section{3.4 Libia}

Dalam website www.moonsighting.com, Libia ternyata memiliki pandangan yang bahkan lebih ekstrim daripada Ijtima Qobla al-Ghurub (IQG). Meskipun Bulan telah mendahului Matahari tenggelam pada hari terjadinya konjungsi, maka Libia telah menetapkan syahnya awal bulan Islam pada pagi berikutnya. Lebih ektrim lagi, Libia bahkan menetapkan awal bulan Islam meskipun ijtima terjadi setelah maghrib, asalkan hilal telah terbentuk pada subuh hari berikutnya (wujudul hilal qabla al-subh WHQS).

\section{E. 3.5 Yordania}

Yordania adalah tempat berkumpulnya para pakar Astronomi pendukung imkan-rukyat (IR). Para ahli dalam ICOP selalu menjadi rujukan para ahli Astronomi pendukung IR di Indonesia. Namun, ternyata dalam penentuan awal Ramadan 1435-H lalu, otoritas politik Yordania tidak menggunakan kriteria IR karena lebih memilih "follow Saudi". Berdasarkan keputusan Mahkamah Agung Arab Saudi, madzhab yang diadopsi adalah rukyatul hilal (RH). Jadi tampaknya pemikiran para pendukung IR tersebut baru terjadi di level riset-riset astonomi yang belum memiliki footings dalam tataran politik dan praktek ritual agama keseharin di Yordania sendiri. Secara praktis mungkin hasilnya sama karena Yordania berarti memulai Ramadan pada 29 Juni 2014 seperti Arab Saudi. Namun, secara prinsip tentu saja landasan hukum antara IR dan RH adalah berbeda.

\section{F. 3.6 Indonesia}

Otoritas politik Indonesia pun tampaknya belum menerima kriteria IR sebagai dasar tunggal untuk penentuan awal Ramadan 1435-H dan pada tahun-tahun sebelumnya. Otoritas politik Indonesia masih lebih memilih Rukyatul Hilal (RH). Ini dibuktikan dengan pengiriman ratusan perukyat ke seluruh pelosok Indonesia untuk mencari dan melihat hilal secara fisik. Persis seperti apa yang dilakukan oleh ISNA dan telah ditinggalkan sejak tahun 2006. Otoritas politik anggota MABIMS juga tampaknya tidak terlalu percaya diri untuk mencantumkan kriteria IR dalam website www.moonsighting.com.

\section{G. 3.7 European Council for Fatwa and Research (ECFR)}

ECFR adalah satu-satunya organisasi riset Islam yang secara terbuka menggunakan metoda wujudul hilal global untuk penentuan awal bulan kalender Islamnya. Ini berarti, jika hilal sudah wujud dimanapun di belahan Bumi (tentu saja di sebelah Barat belahan Bumi), maka hari berikutnya ECFR telah memfatwakan syah masuk dalam bulan Islam baru.

Di pusat ECFR di Dublin, Irlandia, ketinggian hilal pada maghrib 27 Juni 2014 lalu adalah di bawah ufuk $-2.6^{\circ}$. Ini berarti, saat maghrib di Dublin, Bulan telah tenggelam sekitar 13-14 menit mendahului Matahari. Tapi, ECFR telah menetapkan 28 Juni 2014 sebagai awal Ramadan 1435-H. Hasilnya akan sama dengan WHQS 
nya Libia, namun, landasan saintifiknya tentu saja berbeda. Madzhab ini dinamakan wujudul hilal global (WHG). Artinya, jika hilal telah wujud di belahan Bumi manapun, maka seluruh permukaan Bumi telah masuk awal bulan Islam.

Dengan semakin diterimanya madzhab wujudul hilal global dan semakin meningkatnya kesadaran akan pentingnya kalender Islam global, maka tampaknya tren penyusunan kalender Islam sekarang ini seperti bandul yang ditarik ke arah ektrim kiri (WHG) yang dipimpin oleh ECFR. Tidak mustahil, dengan semakin melemahnya tekanan politis ulama tradisional dunia atas madzhab wujudul hilal, ISNA/FCNA juga akan mengikuti jejak ECFR. Organisasi Muslim Indonesia seperti Muhammadiyah, harus mencermati tren global ini. Sementara itu, madzhab imkanrukyat semakin ditinggalkan. Arab Saudi telah meninggalkannya sejak 40 tahun lalu, pemerintah Yordania sebagai gudang tokoh-tokoh Astronomi ICOP pendukung IR juga tidak pernah menunjukkan support politiknya. Turki juga tampaknya sudah meninggalkan madzhab IR dan malah mungkin telah mengikuti ECFR. Demikian juga yang terjadi dengan Libia dll. Tampaknya yang lain segera akan menyusul. Secara diagramatik, konstelasi ketujuh madzhab tersebut dapat dilihat di Gambar 1 berikut.

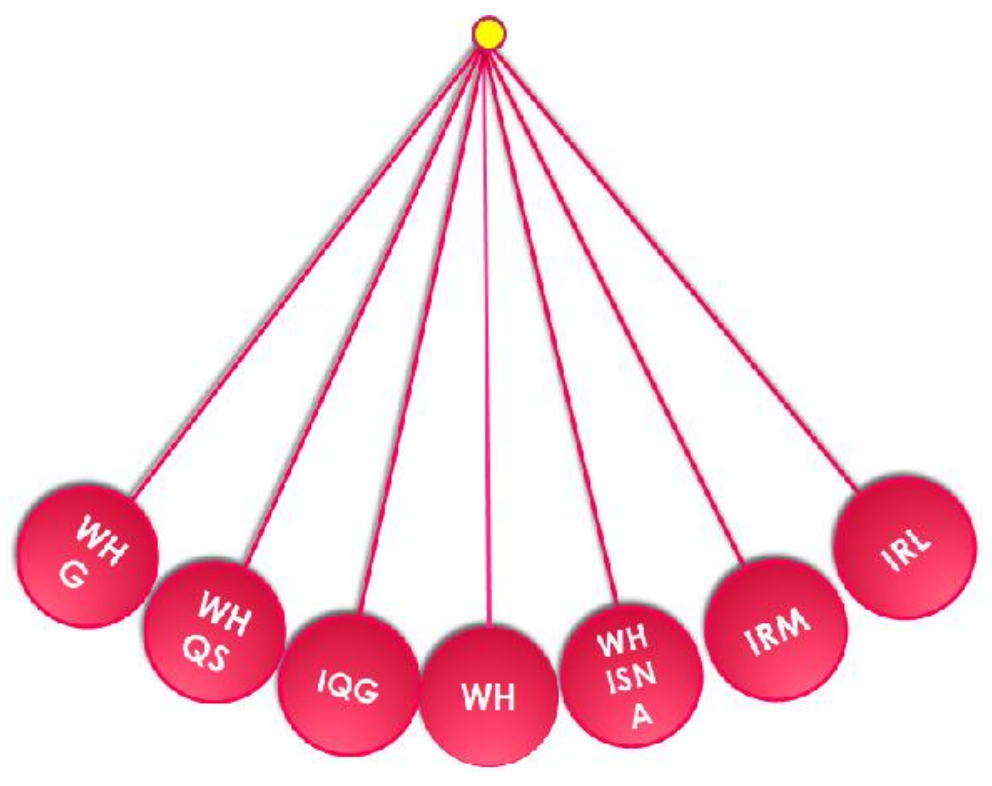

Gambar 1: Tujuh mazhab kriteria penyusunan kalender Islam saat ini

(WHG=wujudul hilal global; WHQS=wujudul hilal qabla as-subh; IQG=ijtimak qablal al-ghurub; WH=wujudul hilal; WH ISNA=wujudulul hilal ISNA; IRM=imkanrukyat MABIMS; IRL=imkan-rukyat LAPAN)

\section{Peran Strategis Muhammadiyah}

Jelaslah, kalender Islam bagi kita semua sekarang ini sebetulnya merupakan masalah paradaban. Lebih tepatnya adalah masalah ancaman atas peradaban Muslim, karena kita telah mewarisi sebuah hutang peradaban akibat ketidakberdayaan nenek moyang kita menjaga kalender Islam sebagai basis manajemen kehidupan muamalah 
kita. Hasil penelitian-penelitian yang dikutip di atas telah membuktikan bahwa semuanya itu telah mengakibatkan konsekuensi syariah.

Bila penduduk dunia melalui WTO baru memikirkan pola distribusi, suplai dan demand barang dan jasa tanpa batas dalam 1-2 dekade terakhir (baca: ekonomi global), maka sebetulnya melalui Islam dunia telah secara spiritual menjadi global sejak lama. Suara adzan dan ritual ibadah harian umat Islam itu sebetulnya tidak pernah terputus (walaupun hanya satu detikpun) dan sambung-menyambung. Ini akibat telah tersebarnya 1.6 miliar umat Islam seperti yang telah ditunjukkan oleh [1], dan perbedaan waktu sholat yang mengikuti tanda astronomis lokal. Akibatnya, adzan subuh di suatu titik di ujung paling barat di Bumi pada satu hari, akan berimpit dengan adzan subuh di suatu titik di paling timur Bumi di hari berikutnya.

Meskipun Muhammadiyah tidak memiliki otoritas politik untuk merubah kesalahan umat terdahulu, setidak-tidaknya Muhammadiyah memiliki kekuatan moral untuk menyadarkan umat, otoritas politik, dan para pelaku bisnis sekarang maupun di masa yang akan datang. Jadi sudah sepatutnya, Muhammadiyah berperan sebagai pionir untuk menyusun sebuah disain roadmap untuk mengatasi ancaman atas peradaban Islam ini.

Sudah saatnya Muhammadiyah sebagai organisasi Islam istiqomah dengan misi pembaharuan (tajdid) memelopori pemikiran ke depan untuk pembangunan Kalender Islam Global untuk kesejahteraan umat. Tanpa harus menunggu MUI dan Kementerian Agama, Muhammdiyah seyogyanya segera membentuk pusat penelitian pembangunan Kalender Islam yang kuat dengan tim peneliti yang lintas disiplin dan terdiri atas pakar-pakar shariah, sains (astronomi, matematik, fisika, statistik), engineering, sosial, politik, ekonomi, komunikasi, sejarah, dll. Dengan memiliki sekitar 170 institusi perguruan tinggi di Indonesia, sebetulnya jaringan para pakar Muhammadiyah ini mungkin merupakan jaringan SDM terbesar di dunia. Pembangunan sebuah institusi riset Islamic Calendar Research Network (ICRN) Muhammadiyah saat ini menjadi sangat relevan dengan tugas-tugas besar sebagai berikut:

1. Ikut menjadi pelopor dalam penelitian dan pembangunan Kalender Islam Global. Jamaluddin Abd ar-Raziq [7] menjelaskan bahwa kalender Islam Global pemersatu (unifikatif) memiliki tujuh syarat penting. Untuk itu, sembilan sistem kalender Islam (yang telah dipraktekkan secara lokal) sedang dikaji oleh para pakar kalender Islam dunia untuk menentukan kalender manakah yang memenuhi ketujuh persyaratan di atas. Para pakar kalender Islam Muhammadiyah harus memiliki kontribusi dalam penelitian yang prestisius ini;

2. Mengkomunikasikan dengan semua stakeholder bahwa dengan rukyatul hilal, tidak mungkin terbentuk kalender Islam, dan karenanya semua stakeholder harus menerima perhitungan hisab. Sementara itu, tren dunia Islam tampaknya sekarang telah menerima hisab, dan menuju ke penerimaan kriteria wujudul hilal global (WHG);

3. ICRN ikut aktif memberikan kontribusi dalam penelitian dan pembangunan Kalender Islam Global;

4. Menghentikan perdebatan tentang kriteria visibilitas hilal imkan-rukyat karena IR telah terbukti merupakan scientific blunder [2] karena bertentangan dengan logika 
akademis seluruh spektrum ilmu pengetahuan. IR pun telah semakin ditinggalkan oleh negara-negara Islam di dunia;

5. Tugas utama tim peneliti ini adalah juga mengkaji lebih jauh hasil temuan tentang hutang peradaban yang disampaikan dalam makalah ini dan hasil-hasil penelitian yang terkait. Selanjutnya ICRN kemudian bertugas untuk melanjutkan misi besar untuk menyusun sebuah roadmap strategis yang bertujuan antara lain:

a) Memberi masukan untuk perbaikan sistem syariah ekonomi yang saat ini masih merupakan psedudo shariah economy. Ekonomi syariah tidak hanya cukup menghindari tiga isu klasik riba, gharar, dan maysir. Ia juga harus menggunakan sistem haul yang syar'i yang berarti mewajibkan penggunaan kalender Islam sebagai basis akuntansi perhitungan laba rugi bisnis umat Islam. Sebagai imbasnya, perhitungan zakat pun akan sinkron dilakukan berdasarkan sistem akuntansi shariah;

b) Melakukan penelitian sejak kapan sebetulnya Muslim mulai melupakan penggunaan kalender Islam sebagai basis akuntansinya, dan menghitung pula total aset umat Islam sekarang ini. Berdasarkan dua parameter tersebut, ahliahli ekonomi makro Muhammadiyah akan mampu menghitung total hutang peradaban umat Islam akibat kekurangan pembayaran zakat karena penggunaan kalender Gregorian sebagai basis akuntansi bisnis umat Islam selama ini;

c) Berdasarkan hasil estimasi pada 3b) di atas, segera menyusun kebijaksanaan strategis untuk skema pembayaran hutang peradaban umat Islam yang sudah menggelembung dan diperkirakan telah mencapai triliunan dolar tersebut. Harus diingat bahwa ini merupakan hutang pada Allah dan harus segera disusun program dan skema pembayarannya.

6. Membangun komunikasi yang intensif dengan pusat-pusat penelitian yang sesuai di seluruh dunia (misal: ECFR di Eropa dan ISNA di Amerika Utara), lembagalembaga keuangan Islam baik bank maupun non-bank;

7. Aktif dalam pertemuan pakar-pakar Islam internasional dan mengkomunikasikan potensi hutang peradaban yang semakin menggelembung jika "pendarahan" ini tidak segera dihentikan;

8. Membangun kerjasama internasional untuk memperoleh dana-dana riset untuk menghitung jumlah hutang peradaban umat Islam akibat kekurangan pembayaran zakat dan skema-skema cara pembayarannya dalam kurun waktu yang disepakati secara internasional;

9. Membangun jaringan, infrastruktur dan lembaga pendidikan untuk melahirkan kader-kader muda peneliti baru di bidang sains dan teknologi baik di tingkat menengah dan perguruan tinggi (strata 1 sampai dengan 3) yang akan mampu menjadi tenaga-tenaga penerus untuk selalu memperbaiki arah dan program roadmap yang ada.

Tentu saja ini akan merupakan tugas besar yang tidak ringan, dan mungkin biaya yang tidak sedikit. Ini hanya akan dapat dilaksanakan jika ICRN Muhammadiyah mampu membangun kerjasama dengan pusat-pusat riset dan pendidikan di dunia. Problem terbesar atas implementasi roadmap ini tentu saja akan terletak pada sikap umat Islam sendiri kelak. Banyak umat Islam yang bahkan mungkin tidak membayar zakat prinsipalnya, apalagi untuk membayar hutang zakat 
yang diwariskan oleh nenek moyang yang bahkan tidak pernah mereka kenal. Sebagai organisasi penjaga moral umat, tentu saja Muhammadiyah tidak boleh menyerah dengan hipotesis yang skeptis ini.

\section{Penutup}

Setelah lebih dari seribu tahun, persoalan Kalender Islam ternyata masih merupakan persoalan besar, padahal ia menyimpan persoalan syariah yang sangat serius. Ini merupakan ladang bahan penelitian yang sangat luas dan memerlukan koordinasi yang baik agar efisien dan efektif. Dengan lebih dari 170 institusi pendidikan di lingkungan Muhammadiyah, secara kuantitattif ini mungkin merupakan jaringan SDM terbesar di dunia. Investasi dalam bidang-bidang penunjang (misalnya laboratorium Falak dan Astronomi) dalam penelitian tentang Kalender Islam harus betul-betul efisien dan efektif. Investasi yang overlap harus dihindarkan agar tidak terjadi pemborosan anggaran yang tidak diperlukan. Keberadaan Islamic Calendar Research Network (ICRN) dengan demikian menjadi sangat penting sebagai pengendali efektifitas investasi dan arah penelitian (dalam tingkat S1 sampai dengan S3).

ICRN dapat juga berperan sebagai semacam clearing house dengan tugastugas strategis untuk memberikan informasi atas arah, kepentingan, dan masa depan penelitian yang terkait dengan Kalender Islam. Ini akan merupakan kelompok think tank tempat berkumpulnya para pakar Kalender Islam Muhammadiyah. ICRN bertugas juga untuk membangun komunikasi dengan dunia internasional yang mungkin dapat menyediakan dana-dana penelitian yang terkait dengan Kalender Islam. Salah satu sumber dana riset adalah dari perbankan syariah dunia. Total aset bank syariah di seluruh dunia diperkirakan berada di kisaran sekitar US \$ 1 triliun. Jika kita menganggap aset Muslim yang disimpan di bank konvensional (non-syariah) dan aset lainnya dalam bentuk paper assets (biasanya di perusahaan-perusahaan nonMuslim), gambar di atas mungkin menjadi sepuluh kali lebih banyak, atau sekitar US $\$ 10$ triliun.

Dari contoh hutang kekurangan pembayaran zakat pada Tabel-2 di atas, jika korporasi pada Tabel-2 tersebut adalah milik Muslim, total defisit pembayaran zakatnya sudah lebih dari US \$ 350 juta. Harus dicatat, itu untuk operasi bisnis yang hanya 10,5 tahun. Jika praktek ini telah berlangsung selama 500 tahun dan melibatkan usaha semua Muslim yang nilai total asetnya US 10 triliun seperti di atas, maka besaran hipotetis hutang peradaban umat Islam mungkin sudah mendekati US \$ 5 triliun. Dengan demikian, jika ICRN dapat meyakinkan bank-bank syariah dunia yang bersedia untuk menghitung potensi kekurangan pembayaran zakatnya, itu akan merupakan sumber dana penelitian yang besar juga. Semua bank syariah di dunia tampaknya telah berpraktek ekonomi syariah yang semu (pseudo). Selain itu, perusahaan non-perbankan lainnya milik umat Islam mungkin juga tertarik untuk mengetahui berapa jumlah defisit pembayaran zakat selama mereka mengoperasikan bisnisnya. Mereka semua bisa didorong untuk menyalurkan bagian-bagian dari dana CSR (corporate social responsibility) mereka untuk membiayai penelitian lebih lanjut dan implementasi roadmap tersebut di atas. Inilah salah satu tugas besar organisasi sekaliber Muhammdiyah melalui ICRN. 


\section{REFERENSI}

1. DeSilver, D. World's Muslim population more widespread than you might think. Factank 2013 [cited 201419 August]; Available from:

http://pewrsr.ch/116QRmk.

2. Saksono, T., Kalender Islam dan Hutang Peradaban Muslim: Tinjauan Ekonomi, Sains dan Teknologi, in Halaqah Nasional Ahli Hisab dan Fikih Muhammadiyah2014, Pimpinan Pusat Muhammadiyah: Yogyakarta.

3. Saksono, T., Disclosing the Huge Potential of Muslims in the Global Economic Development, in i-INNOVA 2014, i.-I. 2014, Editor 2014, University Sains Islam Malaysia: Kuala Lumpur. p. 1.

4. Saksono, T., Pseudo Shariah Economy and Muslims' Civilization Debt. 1 ed 2014, Malaysia: Penerbit UTHM. 255.

5. Gent, R.H.v. The Astronomical Rules Governing the Umm al-Qura Calendar. The Umm al-Qura Calendar of Saudi Arabia, 2012.

6. Saksono, T., Mengkompromikan Rukyat \& Hisab 2007, Jakarta: Amythas Publicita. 276.

7. Anwar, S. Kalender Kamariah Islam Unifikatif. 2004 [cited 20154 June 2015]. 